\title{
Invited commentary on the article, the title "surgical correction of giant extracardiac unruptured aneurysm of the right coronary sinus of Valsalva: Case report and review of the literature"
}

\author{
Nobuhiko Mukohara
}

Received: 4 June 2012/ Accepted: 28 June 2012/Published online: 1 August 2012

(C) The Japanese Association for Thoracic Surgery 2012

The authors described a 52-year-old male with a large right coronary sinus of Valsalva successfully treated by the Bentall operation. Although the patient had no typical sings of Marfan syndrome, the histological examination showed elastic fiber lacking and mucin deposits in the media which resembles the findings of cystic medial necrosis. Choice of surgical procedure seems to be appropriate because if aortic sinus replacement was selected, remaining tissue may cause later events such as aneurysmal change or dissection since histological changes might have occurred in the other part of the aorta. And also long-term results of the Bentall operation are satisfactory with a little complication rate [1, 2]. However, the Bentall operation using a mechanical valve needs lifetime anticoagulation therapy and it is a burden for the patient.

In 1995, David [3] introduced the various surgical techniques of aortic sparing operation in patients with aortic insufficiency and aortic root aneurysm. In the report, sinus replacement was described as a type of remodeling operation.

We have been treated two cases of aneurysm of right sinus of Valsalva with moderate aortic regurgitation. One patient had sinus replacement and aortic valve repair; however, this patient needed a reoperation, aortic valve replacement using a mechanical valve, 5 years after the initial operation due to exacerbation of AR. Another patient with Marfan syndrome underwent reimplantation procedure with use of a 24-mm polyester graft with pseudosinuses [4]. The patient was a 55-year-old female having a $5 \times 5 \mathrm{~cm}$

This comment refers to the article available at doi: 10.1007/s11748-012-0113-4.

\section{N. Mukohara $(\bowtie)$}

Department of Cardiovascular Surgery,

Hyogo Brain and Heart Center at Himeji, 670 Saisho-ko,

Himeji 670-0981, Japan

e-mail: nmukohara@hbhc.jp aneurysm of the right sinus of Valsalva and has been doing well without aortic regurgitation.

In terms of the results of surgery for Marfan syndrome, Patel et al. [5] reported 140 patients in which 56 patients had composite grafts and 84 received valve-sparing operations. There were no hospital deaths in the both group and the patient survival rate at 8 years was $100 \%$ for the valvesparing group and $90.1 \%$ for the composite graft group. In the series by David [6], of 103 patients (26 remodeling and 77 reimplantation technique), there was 1 hospital death and the patient survival rate at 15 years was $87.2 \%$. The aortic valve-sparing operations bring satisfactory results to the patients with Marfan syndrome.

Although the authors applied the Bentall procedure for the patient, valve-sparing operations are another useful option that we have to consider.

\section{References}

1. Hagl C, Strauch JT, Spielvogel D, Galla JD, Lansman SL, Squitieri $\mathrm{R}$, Bodian CA, Griepp RB. Is the Bentall procedure for ascending aorta or aortic valve replacement the best approach for long-term event-free survival? Ann Thorac Surg. 2003;76:698-703.

2. Kouchoukos NT, Wareing TH, Murphy SF, Perrillo JB. Sixteenyear experience with aortic root replacement. Results of 172 operations. Ann Surg. 1991;214:308-20.

3. David TE, Feindel CM, Bos J. Repair of the aortic valve in patients with aortic insufficiency and aortic root aneurysm. J Thorac Cardiovasc Surg. 1995;109:345-52.

4. Nakagiri K, Kadowaki T, Morimoto N, et al. Aortic root reimplantation for isolated sinus of valsalva aneurysm in the patient with Marfan's syndrome. Ann Thorac Surg. 2012;93:e49-51.

5. Patel ND, Weiss ES, Alejo DE, et al. Aortic root operations for Marfan syndrome: a comparison of the Bentall and valve-sparing procedures. Ann Thorac Surg. 2008;85:2003-11.

6. David TE, Armstrong S, Maganti M, et al. Long-term results of aortic valve-sparing operations in patients with Marfan syndrome. J Thorac Cardiovasc Surg. 2009;138:859-64. 